Canadian University Music Review

Revue de musique des universités canadiennes

\title{
R. Larry Todd, ed. Schumann and His World. Princeton: Princeton University Press, 1994. xi, 396 pp. ISBN 0-691-03698-5 (softcover)
}

\section{Glenn Colton}

Volume 17, numéro 2, 1997

URI : https://id.erudit.org/iderudit/1014790ar

DOI : https://doi.org/10.7202/1014790ar

Aller au sommaire du numéro

Éditeur(s)

Canadian University Music Society / Société de musique des universités canadiennes

ISSN

0710-0353 (imprimé)

2291-2436 (numérique)

Découvrir la revue

Citer ce compte rendu

Colton, G. (1997). Compte rendu de [R. Larry Todd, ed. Schumann and His

World. Princeton: Princeton University Press, 1994. xi, 396 pp. ISBN

0-691-03698-5 (softcover)]. Canadian University Music Review / Revue de

musique des universités canadiennes, 17(2), 92-95.

https://doi.org/10.7202/1014790ar

All Rights Reserved (C Canadian University Music Society / Société de musique des universités canadiennes, 1997
Ce document est protégé par la loi sur le droit d'auteur. L'utilisation des services d'Érudit (y compris la reproduction) est assujettie à sa politique d'utilisation que vous pouvez consulter en ligne.

https://apropos.erudit.org/fr/usagers/politique-dutilisation/ 
would have been helpful, if it couldn't appear as an appendix to the book, at least to be referred to it.

The many photographs, particularly those of Medtner himself from age 13 to 70 , enhance the book considerably. I found Plate 13, a photograph with Rachmaninoff taken in 1938, especially revealing; Medtner comes across as the sullen one while Rachmaninoff looks positively cheerful by comparison! Plate 19, a photograph of Medtner at the piano in 1943, is exquisite; the right hand position is remarkable, with the hand and fingers sloping ever so gently from the wrist to the keys.

In sum, this is a fine book that redresses admirably, if not definitively, the lack of reliable sources on Medtner in English. As Ernest Newman wrote in 1925,

[Medtner's] music does not make an immediate appeal to the man in the street, but it certainly grows on the musician. It is as stark and strong as Brahms at his best; there is never a superfluous bar in it, never a superfluous note in the chord; it is sinewy, athletic, and for its weight amazingly flexible, for Medtner is a master of combined and contrasted rhythms. The thought is rarely on the surface, but when one makes it one's own, it is the kind one likes to live with. It is sad to think of the réclame that has come to fifty mediocrities in the last decade or so, while a fine mind like Medtner's goes on its way almost unregarded by the crowd (p. 169).

Martyn's book will undoubtedly help attract a whole new audience to the music of this underrated and underplayed composer, who has, happily, easily outlasted the middling talents that Newman had in mind.

Glen Carruthers

R. Larry Todd, ed. Schumann and His World. Princeton: Princeton University Press, 1994. xi, 396 pp. ISBN 0-691-03698-5 (softcover).

Schumann and His World, edited by R. Larry Todd, combines recent research by several noted Schumann scholars with nineteenth- and early twentieth-century examples of Schumann reception by composers, critics, conductors, and scholars. The book is partitioned neatly into three sections: essays, letters and memoirs, and criticism.

The first section of the book, comprising recent essays by Leon Botstein, Michael Steinberg, Larry Todd, Gerd Nauhaus, John Daverio, Jon Finson, and Bernhard Appel, deals with many diverse aspects of Schumann and his music. These include the composer's position in nineteenth-century German culture, source study and critical reception of selected works, and analytical studies examining topics such as Schumann's symphonic finales and quotation and allusion.

Botstein's essay, "History, Rhetoric, and the Self: Robert Schumann and Music Making in German-Speaking Europe, 1800-1860," examines four aspects of Schumann's life and world: his relationship to the work of Jean Paul and Wolfgang Menzel; the philosophical discourse he encountered as a youth; 
his relationship to his own historical age; and his interest in contemporary art. The strength of this essay is its thorough discussion of German culture as it relates to Schumann. The influence of Menzel upon the composer's critical writings and the relationship of Schumann's style to trends in German art (most notably the directions explored by members of the Düsseldorf and Dresden schools), are two of several such topics discussed. The chief problem with Botstein's writing is that the musical questions raised during the course of discussion are rarely addressed in sufficient detail. On p. 10, for example, Botstein makes the bold claim that "Jean Paul's use of words and formal structure inspired techniques that, owing largely to Schumann's influence, composers emulated in structuring rhythm, melody and harmony within the musical time of a composition." Yet there is no mention as to which composers emulated these techniques, nor are there any musical examples presented to substantiate this line of argument. Similar problems are present in "Schumann's Homelessness" by Steinberg, an essay based on the premise that Mendelssohn and Schumann represent polar opposites in terms of their subjective approaches to music. A more appropriate title for this essay might be "Mendelssohn's Subjectivity and Schumann's Homelessness," since a large portion of it is devoted to Mendelssohn.

One of the highlights of the book is Todd's informative essay "On Quotation in Schumann's Music." In this well-written article, the author assesses instances of quotation and allusion in Schumann's music through a discussion of several examples (some well documented, others more obscure). Todd identifies three general types of quotation/allusion in Schumann's music: references to earlier styles and composers; references to his contemporaries; and self-quotations. Following an analytical discussion of representative works from each type, the author proposes some useful theories for an intertextual reading of Schumann's music. One such theory is that Schumann's allusions generally involve a gradual process of clarification by which implicit references are made explicit as the music progresses. Todd also points out that the composers alluded to in Schumann's music were often the same as those singled out for praise in his critical writings, and that by alluding to works, genres, and compositional techniques of the past, Schumann established a context in which he could "relate his music to an older historical tradition" (p. 103).

The only flaw with Todd's essay is that he occasionally falls into the trap inherent in discussing musical allusions, one which he acknowledges on p. 92: "in a particular example, does the mask indeed conceal a reference; or does reexamination of the evidence suggest that the mask conceals nothing - that there is, in fact, no allusion?" In this light, the reader is left in doubt as to whether the opening of the Scherzo from the Symphony no. 4 in D minor, op. 120 is really borrowed from the Menuetto of Johann Wenzel Kalliwoda's Symphony no. 1, op. 7, as Todd asserts (pp. 102-3), or whether the melodic fragment in question - a stepwise progression in imitation (preceded by a rise of a perfect fourth from the dominant to tonic scale degrees) - is actually employed as a generic formula owing nothing to Kalliwoda at all. 
The following essay, by Nauhaus, provides a detailed, yet poorly organized assessment of Schumann's symphonic finales, which he views as transitional between the symphonic finales of the classical period and later nineteenth-century examples (composed during the era of Brahms, Bruckner, and Mahler) in which the finale is the most heavily weighted. Daverio documents an important example of Schumann reception by Eduard Krüger, a musician, critic, and acquaintance of the composer. Krüger wrote a lengthy, although often overlooked review of the secular oratorio Das Paradies und die Peri, which appeared in four installments of the Allgemeine musikalische Zeitung (1845). This review is divided into three sections: issues of genre and text; analysis; and some concluding remarks interspersed with a discussion of form. According to Daverio, Krüger's central argument was "that Schumann is more adept as a composer of instrumental than of vocal music" (p. 132). The author goes on to compare and contrast Krüger's perception of Schumann's music with that espoused by another contemporary, Franz Brendel. As the author illustrates, these reviewers represent two very distinct styles of nineteenth-century criticism: the so-called "philosophical" criticism practiced by Brendel and the more analytical focus evident in the writings of Krüger (p. 143).

Romantic irony in the Eichendorff Liederkreis is the subject of an excellent essay by Finson. In it, the author proposes an alternative interpretation of the song cycle whereby the opening piece of the first published edition (1842), "Der frohe Wandersmann," is substituted for the piece that ultimately took its place in the revised edition of 1849 ("In der Fremde"). Through a combination of musical and textual analysis, Finson builds a convincing case to support his theory that poetic, melodic, and tonal elements of "Der frohe Wandersmann" performed an important role in establishing a context through which the ironic tone of the cycle as a whole could be perceived. The first part of the book closes with a cogent, well-written, and thoroughly researched essay by Appel entitled “'Actually, Taken Directly from Family Life,' Robert Schumann's Album für die Jugend." Through an examination of the work's biographical origins and sources, Appel concludes that there were three phases involved in its genesis: a planned volume of piano exercises for the Schumanns' eldest daughter Marie, a planned anthology of thirty-four works by Schumann and other composers, and, ultimately, an album linking music, pictures, and text.

The second part of the book, "Letters and Memoirs," comprises a series of four contemporary accounts of Schumann by noted composers, critics, and scholars. First, and perhaps most significant, is Nancy Reich's presentation of previously unpublished correspondence between Clara Wieck Schumann and Felix and Paul Mendelssohn. Prefaced with an introduction by Reich, these letters offer insight into several aspects of Robert Schumann's life and music, including the first performances of the First and Second Symphonies and the Leipzig premiere of the Piano Concerto, the personalities of Felix Mendelssohn and Clara Wieck Schumann, and details of Viennese musical life in the 1830s and 1840s. Next we have two recollections of Schumann by the critics Richard Pohl (translated by John Cooper) and Eduard Hanslick (translated by Susan 
Gillespie). Pohl's memoirs of Schumann, published in 1878, offer insight into the composer's years in Düsseldorf (1850-54), while Hanslick's "Robert Schumann in Endenich" (1899) paints a vivid picture of the composer's final years. The "Letters and Memoirs" section concludes with a biographical account of Schumann by Frederick Niecks, a nineteenth-century scholar and son of the violinist Joseph Joachim. Niecks's Robert Schumann (1925) was one of the earliest critical biographies of the composer in English.

The final part of the book documents critical reception of Schumann's music by contemporaries Carl Koßmaly, Franz Brendel, Franz Liszt, Adolf Schubring, and Felix Weingartner. Koßmaly, a composer-critic and original member of the Davidsbund, published a review of Schumann's piano music in the Allgemeine musikalische Zeitung (1844). This review (newly translated by Gillespie), is presented in the present volume. Although it is riddled with vague and subjective commentary, Koßmaly does make some perceptive observations, most notably his underlying assertion that Schumann's piano works - though not widely known at the time of writing - were nonetheless among the most remarkable artistic achievements of the era. Brendel's discussion of Schumann and Mendelssohn (1845, translated by Jürgen Thym), reveals an ambivalence toward both composers which may be largely attributed to the author's aesthetic preferences, while portions of Liszt's series of articles on Schumann in the Neue Zeitschrift für Musik (1855, translated here by Cooper, Christopher Anderson, and Todd), shed light on the complex yet generally amiable relationship between the two composers. "The Present Musical Epoch and Robert Schumann's Position in Music History" is the title of an 1861 article by Adolf Schubring in which the author proposes an art-based classification of music history divided into three epochs: the architectonic, the plastic, and the painterly. Schumann, according to Schubring, was the first representative of the painterly epoch. The book concludes with a highly critical assessment of Schumann's symphonic writing by the conductor Weingartner. Derived from three late nineteenth- and early twentieth-century sources, Weingartner's remarks even suggest revisions to certain orchestral scores. His suggested alterations to one such work, the Symphony No. 3 in E-flat major, op. 97 ("Rhenish") are listed in the present volume (translated by Todd).

Schumann and His World represents a significant achievement in the study of nineteenth-century music. New and innovative research encompassing a wide spectrum of methodological approaches and subjects is combined with historical accounts to produce balanced view of the composer, his music, and his historical position in nineteenth-century German culture.

Glenn D. Colton 